Indexed by

\title{
Scopus
}

\section{AN EXPERIMENTAL INVESTIGATION OF THE EFFECT OF NATURAL FIBER TREATMENT AND MARINE ENVIRONMENT ON CANNABIS SATIVA/EPOXY LAMINATES}

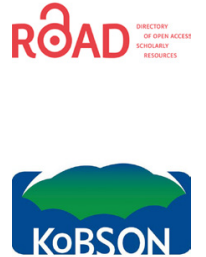

\section{K. N. Chethan}

Manipal Academy of Higher Education, Manipal Institute of Technology, Department of Aeronautical and Automobile Engineering, Karnataka, India

\section{Hegde Sharun}

Manipal Academy of Higher Education, Manipal Institute of Technology, Department of Aeronautical and Automobile Engineering, Karnataka, India

\section{Rajesh Kumar}

Swami Vivekananada Subharti University, Meerut, India

\section{N. H. Padmaraj}

Manipal Academy of Higher

Education, Manipal Institute of Technology, Department of Aeronautical and Automobile Engineering, Karnataka, India

Key words: treated, untreated, ageing, sea-water, modulus doi:10.5937/jaes0-30277

Cite article:

Chethan, K. N., Sharun, H., Kumar, R., Padmaraj, N. H. (2021) AN EXPERIMENTAL INVESTIGATION OF THE EFFECT OF NATURAL FIBER TREATMENT AND MARINE ENVIRONMENT ON CANNABIS SATIVA/EPOXY LAMINATES, Journal of Applied Engineering Science, 19(3), 841-847, DOI:10.5937/jaes0-30277 


\title{
AN EXPERIMENTAL INVESTIGATION OF THE EFFECT OF NATURAL FIBER TREATMENT AND MARINE ENVIRONMENT ON CANNABIS SATIVA/EPOXY LAMINATES
}

\author{
K. N. Chethan ${ }^{1}$, Hegde Sharun 1 , Rajesh Kumar', N. H. Padmaraj ${ }^{1 *}$, \\ ${ }^{1}$ Manipal Academy of Higher Education, Manipal Institute of Technology, Department of Aeronautical and \\ Automobile Engineering, Karnataka, India \\ ${ }^{2}$ Swami Vivekananada Subharti University, Meerut, India
}

Materials have helped in evolving technology to a great extent. Composites have replaced conventional metals/ non-metals because of their lightweight. Natural Fibers have been need of the hour owing to environmental concerns and ease of availability. In this work, Cannabis Sativa fibers were treated with $5 \%$ Potassium Hydroxide solution. The laminates were prepared by the Compression Moulding technique by reinforcing treated and untreated fibers with an epoxy matrix material. To access the durability of natural fiber composites in the marine environment, prepared laminates were aged in seawater for 150 days. Tensile, flexural and moisture absorption behavior tests have been performed to estimate the durability in seawater. The data obtained have been compared with pristine treated and untreated fiber reinforced samples. From the results, it has been observed that tensile and flexural behavior of untreated fiber reinforced composites were superior to a treated counterpart in both pristine and aged conditions.

Key words: treated, untreated, ageing, sea-water, modulus

\section{INTRODUCTION}

Composite contains two important components namely the fiber and matrix phase. The role of fiber is to make them stronger, firm and bears the load. The property of the matrix is that it is consistent, holds the fiber intact and provides shape to the structures [1]. Fiber and matrix can distinguished one from the other in composite material but together they exhibit properties that cannot be attained by individual material [2]. Natural fibers are usually obtained from either plants or animals[3],[4]. They can be easily recycled and hence environmentally friendly [5], [6]. Some other benefits of using natural fiber over synthetic fibers include reasonably priced, low weight, available in large quantities, negligible damage environment [7]. Some of the most common techniques to extract fibers from plants is by decortication and retting. In retting, the woody part of stem undergoes biological treatment which results in the fibers falling apart whereas in decortication a machine called decorticator pulls out the fibers from the leaf or stem [8-10].

Cellulosic fibers of plants can be categorized into bast, seed, leaf, reed, grass and core fibers. Some examples of bast fibers include jute, flax, hemp, ramie, and kenaf [11]. However, these natural fibers have some minor setbacks these include moisture uptake and also improper adhesion with the matrix material. But this can be addressed by subjecting to specific surface treatments of which reduces the water intake together with improvement incompatibility between fiber and matrix [12], [13]. The mechanical conduct of Natural Fiber Reinforced Composites (NFRCs) depends on various parameters these include fiber orientation, moisture absorption, im- purities, physical properties, and volume fraction [14], [15], [16], [17], [18], [19].

Cannabis Sativa or hemp has been grown and harvested once a year. The seeds and fibers of hemp are in most demand. Cultivation of this crop was banned in most developed countries due to its usage as an illicit drug[20]. These fibers have a wide variety of applications such as in agriculture, textile, bio-composite, paper-making, automotive, construction, biofuel, functional food, oil, cosmetics, personal care, and pharmaceutical. The woody portion of the hemp plant and tissues have more lignin can be utilized for bedding of horses, pulping and concreting [21]. Presence of more cellulose and also since it is cultivated on a large scale hence it can also serve as biomass [22]. The rise of demand for such crops is due to more yield combined with viability [23].

The present research work is focused to understand the effect of fiber treatment on tensile and flexural behavior of Hemp/Epoxy laminates. The study also focuses to evaluate the durability of natural fiber-reinforced composites in the marine environment. Fibers were treated with 5\% Potassium Hydroxide $(\mathrm{KOH})$ solution and laminates were prepared by the compression molding process. The prepared laminates were aged in natural seawater for 150 days in ambient conditions. Fourier Transform Infrared Spectroscopy and Scanning electron microscope images were used to study the treatment effect on fiber and tensile failure surface morphology respectively. 


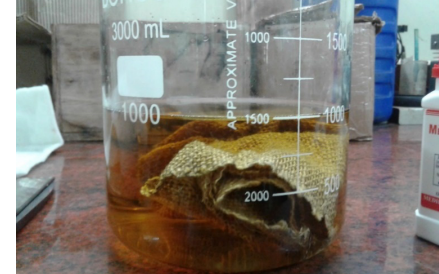

Figure 1: Alkaline treatment of hemp fibers

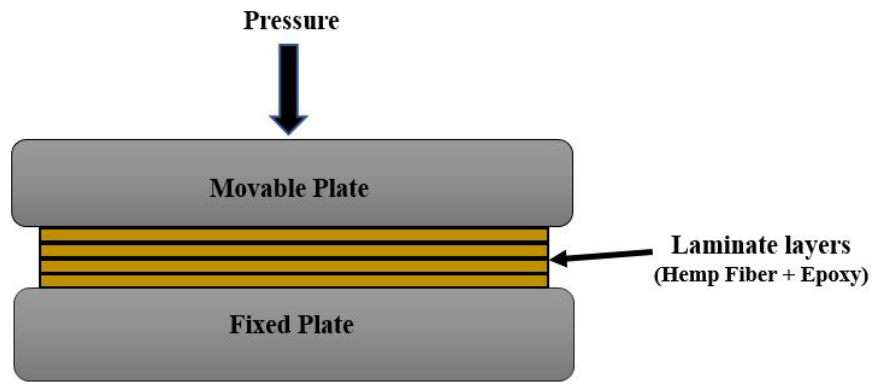

Figure 2: Representation of the laminate preparation process

\section{MATERIALS \& METHODS}

\section{Materials}

Bidirectional Hemp fiber (BF $31 \mathrm{~A}$ ) with an aerial weight of 400 GSM were procured from Hemp Fabric Lab, Mumbai, India. The density of the procured hemp fabric was $1.48 \mathrm{~g} / \mathrm{cm}^{3}$. Laminates were prepared by reinforcing treated and untreated fibers with the thermoset matrix material. Atul grade Epoxy (Lapox L-12) with a gel time of 45 minutes and K-6 hardener were obtained from Yuje Enterprises, Bangalore, India.

\section{Alkali treatment of fibers}

In the present work, hemp fibers were treated with 5\% $\mathrm{KOH}$. Initially, the fibers were pre-washed with distilled water for 1 hour to clear the fibers from any dirt. Later the fibers were dipped in $5 \% \mathrm{KOH}$ and kept in the solution for 2 hours as shown in Figure 1.

After the treatment fibers were washed with distilled water to remove any $\mathrm{KOH}$ bound to the fiber surface. The treated fibers were allowed to dry in ambient temperature for 48 hours.

\section{Laminate preparation}

The treated and hemp/epoxy and untreated hemp/epoxy examined in this study virtually identical by all means (Fiber weight fraction, Number of layers and fabrication method). The specimens were prepared by reinforcing 4 layers of bi-directional treated and untreated hemp fibers with the epoxy matrix material. Initially, two mild steel plates bearing dimensions of $300 \times 300 \mathrm{~mm}$ is chosen and cleaned with acetone to remove any dirt on the surface. Later a coat of release agent is applied to both the plates. The laminate consisting of 4 layers of fibers and a mixture of resin and hardener in between each layer as well as a layer on either side of reinforcement was prepared by hand lay-up technique. Finally, a sheet of peel ply bearing dimension of $300 \times 300 \mathrm{~mm}$ was placed on this to prevent any foreign particles from entering it. To obtain consistent quality and equal thickness the prepared laminates were compressed using compression molding machine and schematic representation of the same as shown in Figure 2.

The compressed laminates allowed to cure in a pressed stage for 24 hours in ambient conditions. The average thickness of the prepared laminate was found to be 2.5 $\mathrm{mm}$. The density of the specimens was measured using Archimedes principle. 30 specimens were used to obtain the average density and were found to be $1.368 \pm 0.16 \mathrm{~g} / \mathrm{cm}^{3}$.

\section{Accelerated ageing}

In the field of civil engineering and marine industry, composite materials were exposed to different service conditions. To understand the interaction between seawater and natural fiber-reinforced composites the prepared laminates were immersed in seawater for 150 days in ambient conditions. Seawater required for the aging process was collected from the Arabian Sea at the western coastal region of Karnataka. Two rectangular $(50 \times 50 \times 2.5$ $\mathrm{mm}$ ) specimens of untreated fiber-reinforced composites (UFRC) and treated fiber-reinforced composites (TFRC) were used to monitor the moisture absorption behavior of the laminates. Moisture concentration of the laminates during the ageing period in regular intervals monitored and expressed by using gravimetric Equation 1 [32, 33]. The initial weight and weight of the specimens in equal intervals monitored using $0.001 \mathrm{mg}$ accuracy digital weighing scale.

$M(t)=\left(\frac{W_{t}-W_{i}}{W_{i}}\right) \times 100$

Where $M(t)$ is the moisture content of the material at any time in $\%, W_{i}$ is the dry or initial weight and $W_{t}$ is the wet weight of the samples.

\section{Tensile test}

The tensile properties of untreated fiber-reinforced composites (UFRC) and treated fiber-reinforced composites (TFRC) were investigated as per ASTM 3039 with a dimension of $250 \times 25 \times 2.5 \mathrm{~mm}$ [32]. Tests were conducted using $50 \mathrm{kN}$ BiSS make Universal Testing Machine with a crosshead speed of $2 \mathrm{~mm} / \mathrm{min}$. To obtain the average failure stress and strain five replicates of specimens were used in each condition. The maximum failure stress and strain of each specimen were calculated from the data obtained.

\section{Flexural test}

The flexural test was carried out on UFRC and TFRC as per ASTM D 790-03 with the help of FIE make 50 kN Universal Testing Machine. Tests were conducted by maintaining a gauge length of $75 \mathrm{~mm}$ and a width of 13 $\mathrm{mm}$. The maximum load at which it buckles is obtained 
along with the displacement is noted. Flexural strength and modulus for every specimen is calculated from the data obtained.

\section{RESULTS \& DISCUSSION}

\section{Chemical Analysis}

Fourier Transform Infrared Spectroscopy (FTIR) analysis was used to characterize and to compare the chemically modified hemp fiber with untreated hemp fiber. Figure 3 shows the infrared spectra in the range of $4000-500$ $\mathrm{cm}-1$ for untreated and treated hemp fiber. Untreated fiber showed the presence of hydroxyl group in the wavelength between $3500-3000 \mathrm{~cm}-1$. But treated fiber showed elimination of hydroxyl group: which will reduce the affinity towards moisture. Also, 3000-2500 cm-1 indicates the $\mathrm{C}-\mathrm{H}$ bond stretching for untreated hemp fibers. The treatment of fiber with $\mathrm{KOH}$ eliminated this group and indicates the removal of lignin from the fiber surface. At $1650 \mathrm{~cm}-1$ shows the carbonyl group stretching which designates removal of hemicellulose [28], [34], [35], [36].

\section{Moisture absorption behavior}

Exposure of polymer matrix composites to humid or water environments will induce absorption of moisture into the material by a diffusion process. The Figure 4 shows the moisture absorption behavior of UFRC and TFRC laminates as a function of immersion time.

Surface modification of Hemp fabric with $\mathrm{KOH}$ reduced the water affinity of the fibers and resulted in a lower amount of moisture intake as compared to UFRC. During the aging process, both specimens exhibited two stages of moisture absorption phenomenon by following Fick's law of diffusion. In the initial immersion period, a higher rate of moisture uptake process was observed at 650 hours of immersion both specimens reached to saturation point or an equilibrium point. At saturation point, UFRC and TFRC absorbed 9 and $8 \%$ of moisture respectively as compared to their initial weight.

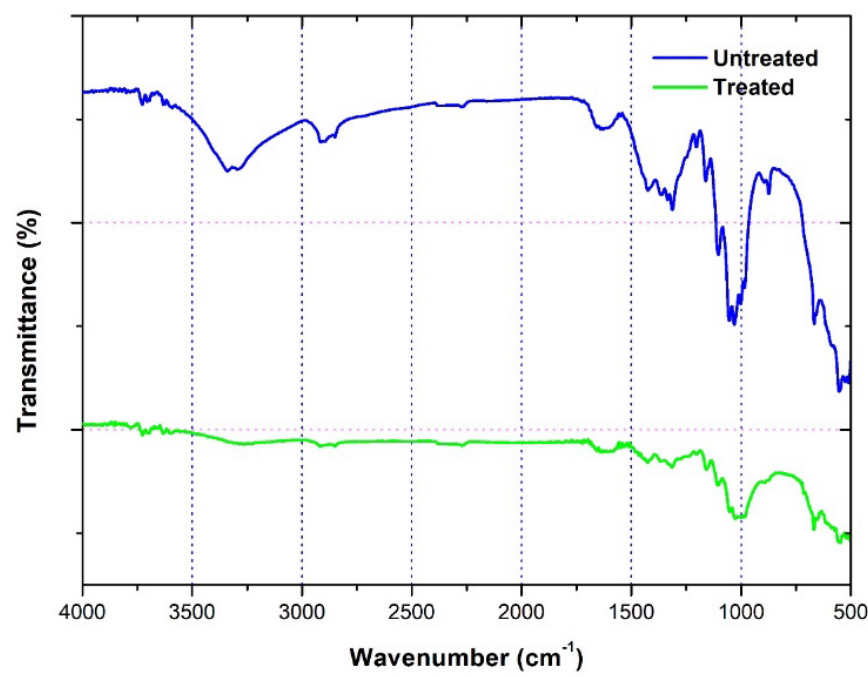

Figure 3: FTIR spectra of treated and untreated Hemp fiber

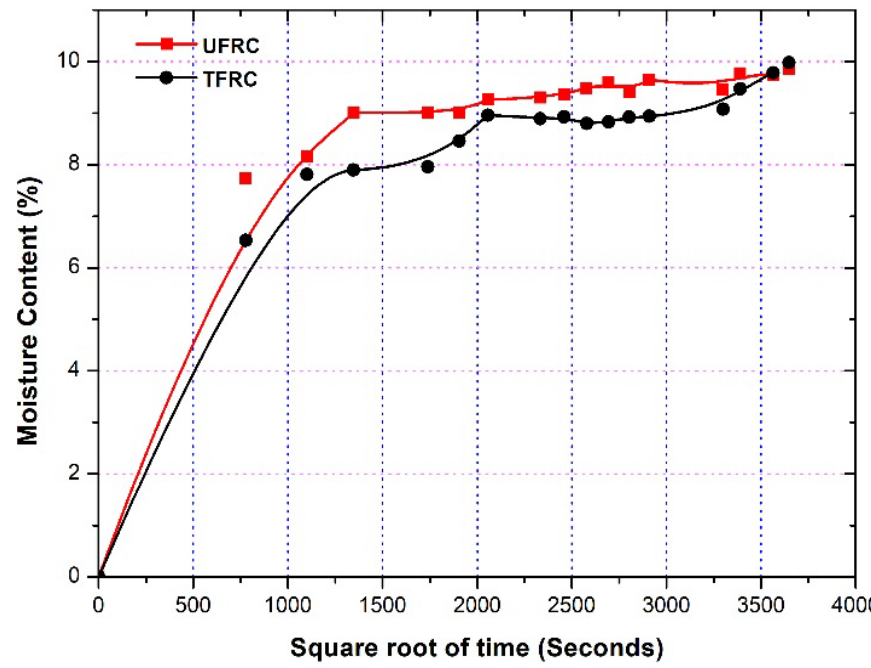

Figure 4: Moisture absorption behavior of UFRC and TFRC hemp/epoxy laminates

\section{Tensile Test}

The tensile properties of the composite material mainly depended upon the fiber/matrix bonding, fiber content, void content and moisture absorption rate. Table 1 and 2 shows the variation of tensile properties of untreated and treated Hemp/Epoxy laminates at different aging period. In each test 5 samples used to obtain the aver-

Table 1: Effect of ageing duration on tensile properties of UFRC hemp/epoxy laminate

\begin{tabular}{|c|c|c|c|}
\hline $\begin{array}{c}\text { Ageing } \\
\text { duration } \\
\text { (Days) }\end{array}$ & $\begin{array}{c}\text { Average } \\
\text { Tensile Stress } \\
(\mathbf{M P a})\end{array}$ & $\begin{array}{c}\text { Average } \\
\text { Failure strain } \\
(\mathbf{m m} / \mathbf{m m})\end{array}$ & $\begin{array}{c}\text { Average } \\
\text { Modulus } \\
(\mathbf{G P a})\end{array}$ \\
\hline 0 & $36.478 \pm 3.066$ & $0.036 \pm 0.006$ & $0.855 \pm 0.028$ \\
\hline 30 & $34.383 \pm 1.913$ & $0.033 \pm 0.005$ & $0.831 \pm 0.021$ \\
\hline 90 & $31.620 \pm 4.847$ & $0.034 \pm 0.001$ & $0.798 \pm 0.016$ \\
\hline 150 & $31.570 \pm 1.604$ & $0.0355 \pm 0.002$ & $0.766 \pm 0.029$ \\
\hline
\end{tabular}

Table 2: Effect of ageing duration on tensile properties of TFRC hemp/epoxy laminate

\begin{tabular}{|c|c|c|c|}
\hline $\begin{array}{c}\text { Ageing } \\
\text { duration } \\
\text { (Days) }\end{array}$ & $\begin{array}{c}\text { Average } \\
\text { Tensile Stress } \\
\text { (MPa) }\end{array}$ & $\begin{array}{c}\text { Average } \\
\text { Failure strain } \\
(\mathbf{m m} / \mathbf{m m})\end{array}$ & $\begin{array}{c}\text { Average } \\
\text { Modulus } \\
\text { (GPa) }\end{array}$ \\
\hline 0 & $32.246 \pm 0.831$ & $0.043 \pm 0.004$ & $0.754 \pm 0.032$ \\
\hline 30 & $28.556 \pm 0.985$ & $0.036 \pm 0.008$ & $0.721 \pm 0.017$ \\
\hline 90 & $25.916 \pm 2.642$ & $0.034 \pm 0.008$ & $0.685 \pm 0.037$ \\
\hline 150 & $23.248 \pm 2.149$ & $0.035 \pm 0.004$ & $0.681 \pm 0.037$ \\
\hline
\end{tabular}

age failure stress and strain of the material. The analysis of obtained results shows that UFRCs exhibited better stress-bearing capabilities compared to TFRCs.

Surface modification of fibers was generally used to improve the adhesion between the fiber/matrix interphase. Treatment of fibers with $5 \% \mathrm{KOH}$ resulted in the removal of lignin and hemicellulose from the fiber surface. Also, the treated fibers become stiffer and it's mass also re- 


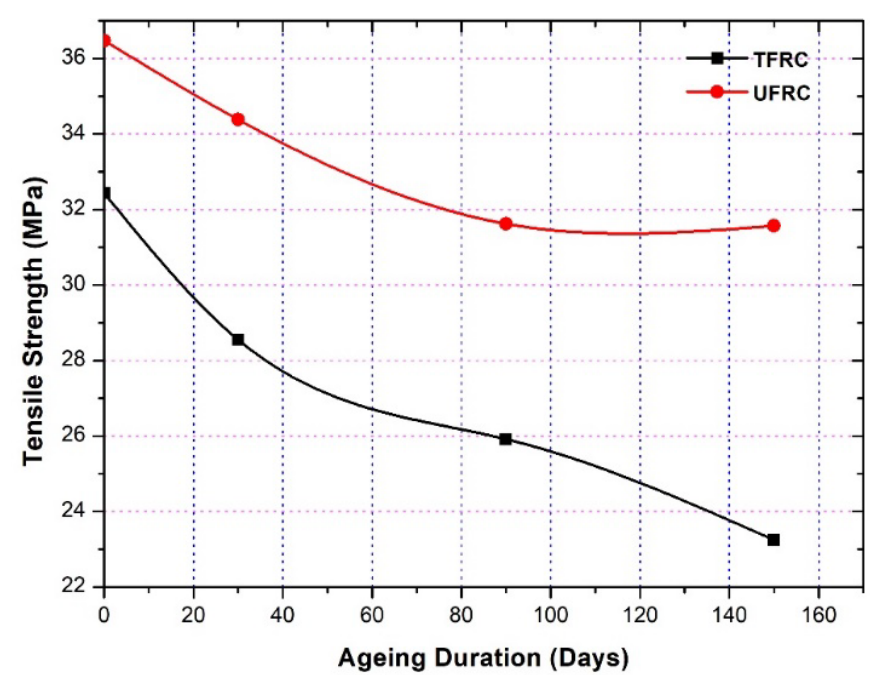

Figure 5: Variation of failure stress of UFRC and TFRC with respect to ageing duration

duced in comparison to untreated ones [37], [38]. Figure 5 shows the variation of failure stress with respect to the aging period for both TFRC and UFRC specimens. In the case of a pristine specimen, TFRC specimens showed a $12 \%$ reduction in maximum failure stress as compared to UFRC. Treatment of fibers with a higher percentage of $\mathrm{KOH}$ resulted in poor interfacial strength and showed a reduction of tensile properties. Modulus of the material varied with respect to aging duration and is shown in Figure 6. The rate of degradation of modulus was dependent upon the rate of moisture uptake and fiber treatment process. At the end of the ageing period, TFRC and UFRC showed a reduction of $15 \%$ and $11 \%$ in modulus as compared to pristine samples.

\section{Flexural Test}

The flexural characteristics of UFRCs/TFRCs in pristine and aged conditions are studied at regular intervals as per ASTM standards and is shown in Figure 7.

From the results, it can be understood that UFRCs exhibit

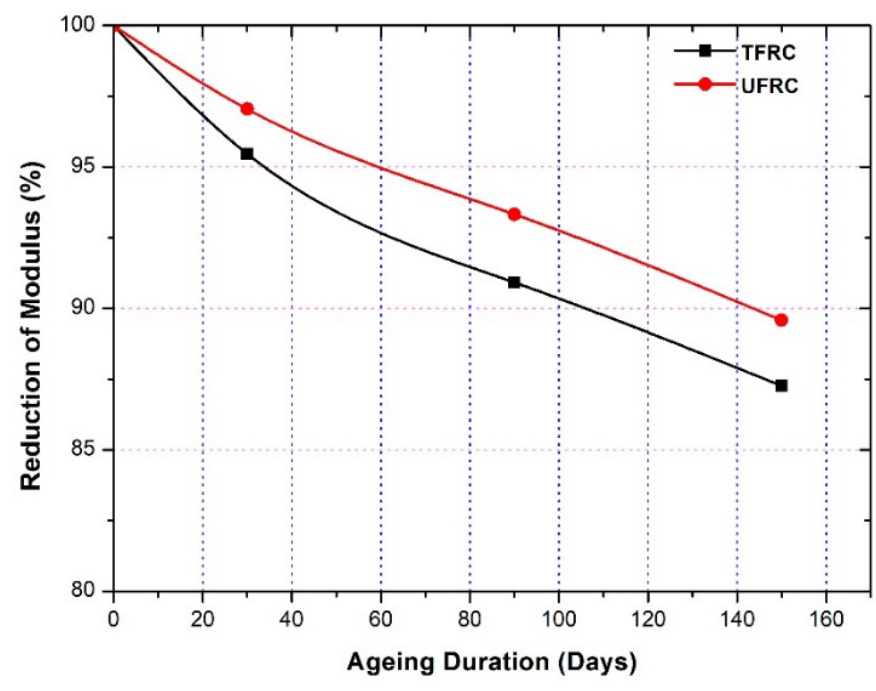

Figure 6: Percentage reduction of Modulus in UFRCs and TFRCs

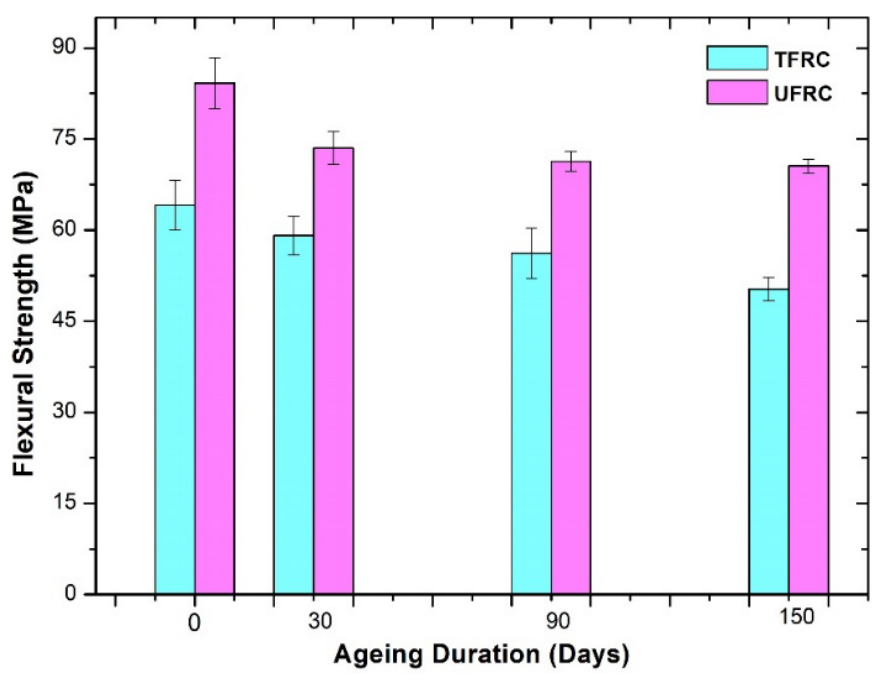

Figure 7: Variation of flexural properties

better flexural strength. Also, the flexural strength of pristine composites (both treated and untreated) was better than their aged counterpart. In the case of pristine specimens; UFRC exhibited a maximum flexural strength of $84.24 \pm 8.17$ MPa while that of TFRCs was $64.10 \pm 4.068 \mathrm{MPa}$. At the end of the ageing process, UFRC and TFRC showed $17 \%$ and $22 \%$ reduction in flexural strength respectively.

\section{Analysis of failure surfaces}

To understand the effect of the ageing process on hemp/ epoxy laminates Scanning electron microscope (SEM) images of the tensile fracture specimens were captured and compared with pristine samples. Figure 8 (a) and (b) shows the SEM images of pristine UFRC and TFRC. SEM images clearly showed the effect of fiber surface treatment on the wetting and coupling process between fiber and matrix interphase. Untreated fibers showed better bonding (Fig. 8(a)) between fiber and matrix surfaces. Inter fiber cracks along the loading direction are the major contributor to the failure of laminates. But in the case of TFRC poor bonding between fiber/matrix interphase is visible (Fig. 8 (b)). Treatment of fibers with $\mathrm{KOH}$ appeared to have a smooth surface and may result in poor interlocking between fiber/matrix interphase and an overall reduction in tensile and flexural properties.

Figure 9 (a) and (b) show the tensile fracture surface UFRC and TFRC of aged specimens. Even though fiber treatment reduced moisture absorption rate as compared to untreated hemp/epoxy laminates; the poor bonding between fiber/matrix surfaces resulted in the decomposition of matrix material from the fiber surface. In the case of UFRC greater bonding observed and tensile loading induced cracks in the matrix surface and resulted in the formation of flakes of epoxy.

\section{CONCLUSION}

The present study was carried out to understand the effect of fiber treatment and the marine environment on the mechanical properties of Hemp/Epoxy laminates. Fibers 

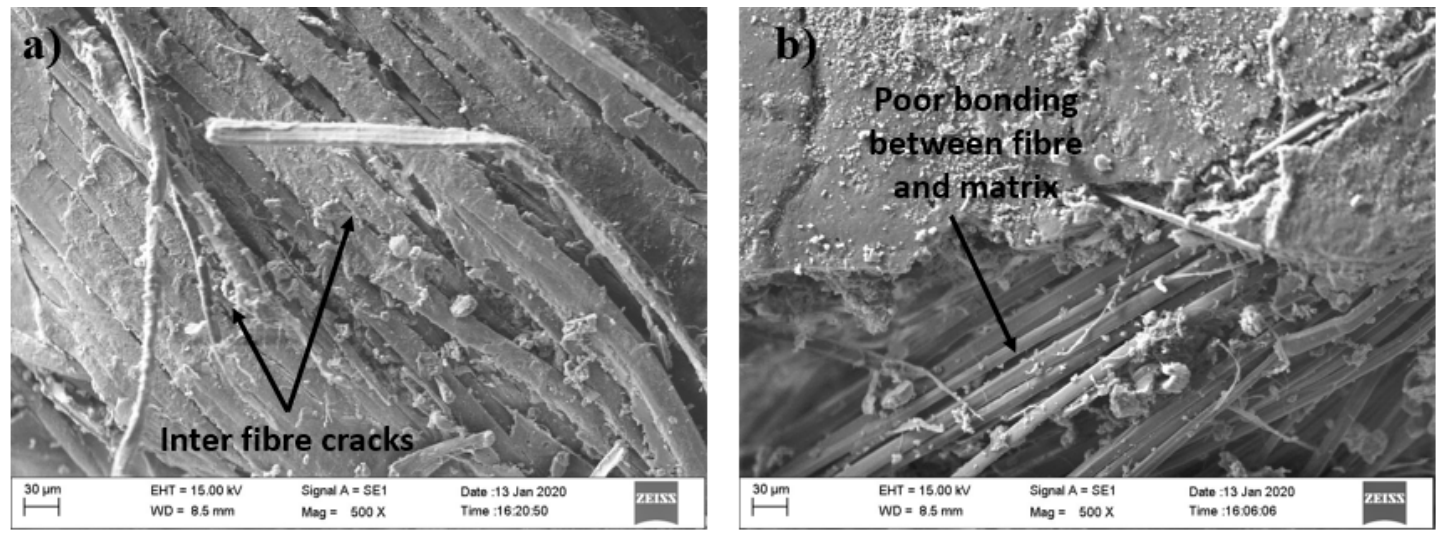

Figure 8: SEM images of tensile fracture specimens (a) UFRC, (b) TFRC
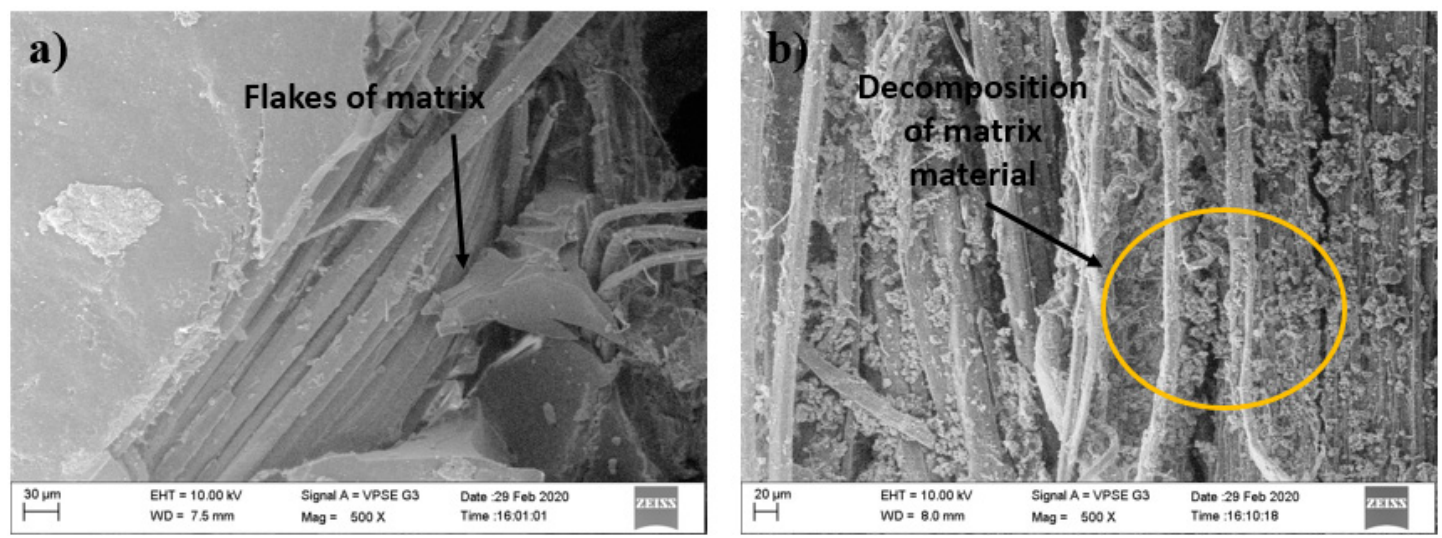

Figure 9: SEM images of tensile fracture specimens after 150 days of ageing (a) UFRC (b) TFRC

were treated with a $5 \% \mathrm{KOH}$ solution. The tensile and flexural characteristics of specimens without treatment were slightly better than the treated counterpart. This is owing to increased alkaline concentration which leads to fibrillation of fibers also makes them stiff and reduced interlocking mechanism of fiber/matrix interphase. Treatment of fiber showed a slight difference in moisture absorption behavior and treated fiber-reinforced laminates absorbed lower moisture content. SEM images revealed the poor adhesion between matrix/fiber interphase in the case of treated fiber-reinforced hemp/epoxy laminates. Hence the treatment of fibers beyond a certain concentration of alkali solution will lead to poor mechanical characteristics.

\section{ACKNOWLEDGMENTS}

The authors thank the Department of Aeronautical and Automobile Engineering, Manipal Institute of Technology, Manipal Academy of Higher Education, Manipal for providing the composite laboratory to conduct the experiments.

\section{REFERENCES}

1. Ranga P; Singhal S; Singh I. (2014). A Review Paper on Natural Fiber Reinforced Composite; International Journal of Engineering Research \& Technology; Vol. 3:467-9.

2. Mallick PK. (2007). Fibre-reinforced composites materials, manufacturing and design; CRC Press, New York, doi:10.1016/0010-4361(89)90651-4.
3. Mohammed L; Ansari MNM; Pua G; Jawaid M; Islam MS. (2015). A Review on Natural Fiber Reinforced Polymer Composite and Its Applications. International Journal of Polymer Science; doi:10.1155/2015/243947.

4. Ticoalu A; Aravinthan T; Cardona F.(2010). A review of current development in natural fiber composites for structural and infrastructure applications; Southern Region Engineering Conference.

5. May-Pat A; Valadez-González A; Herrera-Franco PJ. (2010). Effect of fiber surface treatments on the essential work of fracture of HDPE-continuous henequen fiber-reinforced composites. Polymer Testing; Vol 32; No 6; doi:10.1016/j.polymertesting.2013.06.006.

6. Padmaraj NH, Keni LG, Chetan KN, Shetty M. (2018). Mechanical Characterization of Areca husk-Coir fiber reinforced hybrid Composites. Materials Today Proceedings ;Vol 5; No 1; 1292-7. doi:10.1016/j. matpr.2017.11.214.

7. Shalwan A, Yousif BF. (2013). In State of Art: Mechanical and tribological behaviour of polymeric composites based on natural fibres. Materials \& Design; Vol 48:14-24. doi:10.1016/j.matdes.2012.07.014. 
8. Awwad E, Mabsout M, Hamad B, Talal M, Khatib H.(2020). Studies on fiber-reinforced concrete using industrial hemp fibers. Construction and Building Materials; Vol 35; 710-717. doi:10.1016/j.conbuildmat.2012.04.119.

9. Huaran H, Hao L, Guanghui D, Fei Y, Gang D, Yang Y. (2019). Fiber and seed type of hemp ( Cannabis sativa $L$.) responded differently to salt-alkali stress in seedling growth and physiological indices. Industrial Crops and Products; Vol 129; 624-30. doi:10.1016/j. indcrop.2018.12.028.

10. Gohil P, Patel K, Chaudhary V. (2019). Natural fiber-reinforced polymer composites: a comprehensive study on machining characteristics of hemp fiber-reinforced composites. Biomass, BiopolymerBased materials and Bio energy; doi:10.1016/B9780-08-102426-3.00002-3.

11. Faruk O, Bledzki AK, Fink HP, Sain M. (2012). Biocomposites reinforced with natural fibers: 2000 2010. Progress in Polymer Science; Vol 37; No 11; doi:10.1016/j.progpolymsci.2012.04.003.

12. Ray SS, Bousmina M. (2005). Biodegradable polymers and their layered silicate nanocomposites: In greening the 21st century materials world; Progress in Materials Science; Vol 50:962-1079. doi:10.1016/j. pmatsci.2005.05.002.

13. Hegde S, Satish Shenoy B, Chethan KN. (2019). Review on carbon fiber reinforced polymer (CFRP) and their mechanical performance. Materials Today Proceedings; Vol 19; 658-62. doi:10.1016/j.matpr.2019.07.749.

14. Ren B, Mizue T, Goda K, Noda J. (2012). Effects of fluctuation of fibre orientation on tensile properties of flax sliver-reinforced green composites. Composite Structures. Vol 94; No 12; doi:10.1016/j.compstruct.2012.06.002.

15. Pan Y, Zhong Z. (2015). A micromechanical model for the mechanical degradation of natural fiber reinforced composites induced by moisture absorption. Mechanics of Materials. Vol 85. doi:10.1016/j.mechmat.2015.02.001.

16. Jayamani E, Hamdan S, Rahman R, Khusairy M. (2014). Investigation of Fiber Surface Treatment on Mechanical , Acoustical and Thermal Properties of Betelnut Fiber Polyester Composites. Procedia Engineering; Vol 97:545-54. doi:10.1016/j.proeng.2014.12.282.

17. Boopathi L, Sampath PS, Mylsamy K. (2012). Investigation of physical, chemical and mechanical properties of raw and alkali treated Borassus fruit fiber. Composites Part B Engineering. Vol 43; No 8; doi:10.1016/j.compositesb.2012.05.002.
18. Ramesh M, Sri Ananda Atreya T, Aswin US, Eashwar H, Deepa C. (2014). Processing and mechanical property evaluation of banana fiber reinforced polymer composites. Procedia Engineering. Vol 97. doi:10.1016/j.proeng.2014.12.284.

19. Shahzad A. Hemp fiber and its composites - A review. (2012). Journal of Composite Materials; Vol 46; No 8; 973-86. doi:10.1177/0021998311413623.

20. Salentijn EMJ, Zhang Q, Amaducci S, Yang M, Trindade LM. (2015). New developments in fiber hemp (Cannabis sativa L.) breeding. Industrial Crops and Products; Vol 68; 32-41. doi:10.1016/j.indcrop.2014.08.011.

21. Elfordy S, Lucas F, Tancret F, Scudeller Y, Goudet L. (2008). Mechanical and thermal properties of lime and hemp concrete ("hempcrete") manufactured by a projection process. Construction and Building Materials; Vol 32; doi:10.1016/j.conbuildmat.2007.07.016.

22. Hanegraaf MC, Biewinga EE, Van Der Bijl G. (1998). Assessing the ecological and economic sustainability of energy crops. Biomass and Bioenergy. doi:10.1016/S0961-9534(98)00042-7.

23. FAO/ICAC. World apparel fiber consumption survey. (2013).

24. Pejic BM, Kostic MM, Skundric PD, Praskalo JZ. (2008). The effects of hemicelluloses and lignin removal on water uptake behavior of hemp fibers. Bioresource Technology. Vol 99; No 15. 152-9. doi:10.1016/j.biortech.2007.12.073.

25. Zegaoui A, Derradji M, Ma R, Cai W, Medjahed A. (2018). Influence of fiber volume fractions on the performances of alkali modified hemp fibers reinforced cyanate ester/benzoxazine blend composites. Materials Chemistry and Physics. Vol 123. doi:10.1016/j. matchemphys.2018.04.012.

26. Liu W. (2018). The influence of different chemical treatments on the hemp fiber/polybenzoxazine based green composites: Mechanical, thermal and water absorption properties. Materials Chemistry and Physics. Vol 217. doi:10.1016/j. matchemphys.2018.06.040.

27. Barari B, Omrani E, Moghadam AD, Menezes PL, Pillai KM, Rohatgi PK. (2016). Mechanical , Physical and Tribological Characterization of Nano- Cellulose Fibers Reinforced Bio-Epoxy Composites: An Attempt to Fabricate and Scale the ' Green ' Composite. Carbohydrate Polymer. Vol 147. doi:10.1016/j. carbpol.2016.03.097. 
28. Xu Y, Dayo AQ, Wang J, Wang A, Lv D, Zegaoui A. (2018). Mechanical and thermal properties of a room temperature curing epoxy resin and related hemp fibers reinforced composites using a novel in-situ generated curing agent. Materials Chemistry and Physics. Vol 203. 293-301. doi:10.1016/j. matchemphys.2017.10.004.

29. Latha PS, Rao MV, Raghavendra G, Ojha S. (2015). Evaluation of mechanical and tribological properties of bamboo - glass hybrid fiber reinforced polymer composite. Journal of Industrial Textiles. Vol 46; No 1. doi:10.1177/1528083715569376.

30. Sanjay MR, Madhu $P$, Jawaid M, Senthamaraikannan P, Senthil S, Pradeep S. (2018). Characterization and properties of natural fiber polymer composites: A comprehensive review. Journal of Cleaner Production. Vol 172. 566-81. doi:10.1016/j. jclepro.2017.10.101.

31. Sair S, Oushabi A, Kammouni A, Tanane O, Abboud Y, Hassani FO. (2017). Effect of surface modi fi cation on morphological , mechanical and thermal conductivity of hemp fiber : Characterization of the interface of hemp - Polyurethane composite. Case Studies in Thermal Engineering. Vol 10. 550-9. doi:10.1016/j. csite.2017.10.012.

32. Padmaraj $\mathrm{NH}$, Chethan $\mathrm{KN}$, Utkarsh S, Banerjee $\mathrm{S}$, Utkarsh. (2018). Influence of marine environment on mechanical properties of glass fiber reinforced composites. IOP Conference Series Material Science Engineering. doi:10.1088/1757-899X/377/1/012132.

33. Chilali A, Zouari W, Assarar M, Kebir H, Ayad R. (2017). Effect of water ageing on the load-unload cyclic behaviour of flax fibre-reinforced thermoplastic and thermosetting composites. Composite Structures. Vol 183. doi:10.1016/j.compstruct.2017.03.077.
34. Dayo AQ, Zegaoui A, Nizamani AA, Kiran S, Wang J, Derradji M. (2018). The influence of different chemical treatments on the hemp fiber/polybenzoxazine based green composites: Mechanical, thermal and water absorption properties. Materials Chemistry and Physics. Vol 217. 270-7. doi:10.1016/j. matchemphys.2018.06.040.

35. Kabir MM, Wang H, Lau KT, Cardona F. (2013). Effects of chemical treatments on hemp fibre structure. Applied Surface Science. Vol 276. 13-23. doi:10.1016/j.apsusc.2013.02.086.

36. Dai D, Fan M, Collins P. (2013). Fabrication of nanocelluloses from hemp fibers and their application for the reinforcement of hemp fibers. Industrial Crops and Products. Vol 44. 192-9. doi:10.1016/j.indcrop.2012.11.010.

37. Efendy MGA, Pickering KL. (2014). Comparison of harakeke with hemp fibre as a potential reinforcement in composites. Composites: Part A Applied Science and Manufacturing. Vol 67. 259-67. doi:10.1016/j.compositesa.2014.08.023.

38. Haghighatnia T, Abbasian A, Morshedian J. (2017). Hemp fiber reinforced thermoplastic polyurethane composite: An investigation in mechanical properties. Industrial Crops and Products. Vol 108. 853-63. doi:10.1016/j.indcrop.2017.07.020. 